Ewa Lipińska

Uniwersytet Jagielloński, Kraków

ewa.lipinska@uj.edu.pl

\title{
DWUJĘZYCZNOŚĆ KOGNITYWNA
}

Słowa klucze: znajomość dwu języków, dwujęzyczność, dwujęzyczność naturalna/inteligencka, bilingwizm kognitywny, język odziedziczony

Keywords: knowledge of two languages, bilingualism, natural/learned bilingualism, cognitive bilingualism, inherited tongue

\section{Wstęp}

Terminologia dotycząca pojęcia dwujęzyczność (bilingwizm) ${ }^{1}$ jest niezwykle obszerna. Na przykład zjawisku, które Leonard Bloomfield (zob. dalej) nazwał po prostu dwujęzycznością, zaczęto przydawać określenia: pełna, całkowita, prawdziwa, czysta, utożsamiać je z podwójnym holilingwizmem, a także bilingwizmem zrównoważonym, czyli ambilingwizmem, a nawet bilingwizmem koordynacyjnym (wspótrzędnym) (Lipińska 2003). Rozróżnienia te, ważne w wymiarze teoretycznym, niewiele wnoszą jednak do sfery praktycznej. Sprawą podstawową jest bowiem ustalenie, czym jest dwujęzyczność (kto jest dwujęzyczny). Taką próbę podjęłam, odróżniając bilingwizm uwarunkowany edukacyjnie od znajomości (dwu) języków (Lipińska 2003). W niniejszym artykule przypominam obydwie

1 Zagadnienie dwujęzyczności od dawna leży w kręgu moich zainteresowań i badań, do czego przyczynił się Szanowny Jubilat. W tym artykule odnoszę się do wcześniejszych moich prac, w których poruszam temat bilingwizmu, zwłaszcza (Lipińska 2003, 2006, 2012, 2013, 2014). Można w nich znaleźć obszerną bibliografię na ten temat. 
definicje $^{2}$, proponując jeszcze silniejsze osadzenie dwujęzyczności w kontekście oświatowo-dydaktycznym, gdyż wiąże się to z możliwością jej zbadania/zmierzenia. Uzupełniam je również o subiektywne i obiektywne czynniki determinujące postrzeganie języczności i kulturowości, a także zwracam uwagę na niejednoznaczność terminu język wyjściowy z uwypukleniem istoty języka odziedziczonego. Swoje rozważania ograniczam do sytuacji, w których jednym z języków jest polski, a drugim - inny europejskỉ łącznie z wersjami występującymi w obu Amerykach i Australii, np.: angielski amerykański, kanadyjski, australijski; francuski kanadyjski; portugalski brazylijski itd. Podlegają one bowiem wytycznym Rady Europy w kwestiach ich ujednoliconego nauczania i testowania, zebranych w Europejskim systemie opisu kształcenia językowego: uczenie się, nauczanie, ocenianie (ESOKJ). Biorąc zaś pod uwagę podział Polaków spoza Polski na 1) autochtoniczne polskie zbiorowości etniczne oraz 2) polonijne skupiska osadnicze i przesiedleńcze kontynentalne (europejskie) oraz zamorskie (Dubisz 1997: 19), koncentruję się na tych drugich.

\section{Dwujęzyczność a znajomość dwu języków}

Uważam, że termin dwujęzyczność/bilingwizm jest nadużywany i traktowany w zbyt szerokim znaczeniu, tymczasem jest to szczególny przypadek znajomości dwóch języków - ojczystego i obcego/drugiego. Pojęcie pierwsze odnieść można do $d w u$ języczności rzeczywistej (genuine bilingualism), drugi - do niby-dwujęzyczności ${ }^{4}$ (pseudo-bilingualism).

Osoba „niby-dwujęzyczna” zna jeden język znacznie lepiej niż drugi, którego nie używa w codziennej komunikacji. Natomiast osoba prawdziwie dwujęzyczna opanowuje obydwa języki od wczesnego dzieciństwa ${ }^{5}$ i ma podobną łatwość w komunikowaniu się w obu (O’Doherty 1958 za: Peal, Lambert 2007: 237).

Znajomość (dwu) języków ${ }^{6}$ zalicza się do różnojęzyczności (ESOKJ: 16), dwujęzyczność zaś jest przykładem wielojęzyczności. W każdym z tych pojęć kluczową rolę odgrywa język ojczysty/pierwszy (tu: polski).

\footnotetext{
2 Zostały one nieznacznie zmodyfikowane w Lipińska 2012, 2014.

3 Wiąże się to z pojęciem dwujęzyczność polsko-obca (Miodunka 2014: 199).

4 W cytowanej pozycji używa się nazwy pseudobilingwizm.

5 Sądzę, że lepszym określeniem byłoby $w$ dzieciństwie, do 12-14 roku życia.

6 Bywa ona utożsamiana $\mathrm{z}$ dwujęzycznością mieszana, niezrównoważona, kompozycyjna.
} 


\subsection{Znajomość dwu języków}

U niektórych (e/i)migrantów polszczyzna jest zdominowana przez język kraju osiedlenia, co oznacza, że jej poziom się obniża ${ }^{7}$ i trudno go porównać z kompetencjami równoważnych wiekowo i społecznie jej rodzimych użytkowników ${ }^{8}$. U innych dominuje nad językiem obcym/drugim, co powoduje, że biegłość w nim nie odpowiada tej, jaką posiadają native speakerzy. Ponadto osoby takie zazwyczaj posługują się dwiema sprawnościami, tj. słuchaniem i mówieniem, tylko w pewnych sytuacjach i z niektórymi uczestnikami aktu komunikacji. Obydwa języki nie są też używane $\mathrm{z}$ jednakową częstością i nie pełnią tych samych funkcji, a kultura rodzima jest (e/i)migrantom bliższa niż lokalna.

Nakreślony stan to znajomość (dwu) języków, wyraźnie osadzona w kontekście „pozakrajowym”. Należy pamiętać, że jest nim również uczenie się języka obcego, widziane jako świadome poznawanie go w warunkach sztucznych, czyli w szkole lub na kursie, w sposób formalny, zaplanowany i kontrolowany. Uczący się mają na ogół nikły kontakt z kulturą docelową. Przykładem może być Polak uczący się angielskiego we Francji.

\subsection{Dwujęzyczność}

Dwujęzyczność to opanowanie dwu języków przez daną osobę w takim stopniu, w jakim znają je wiekowo i społecznie jej odpowiadający ich rodzimi użytkownicy. Polega na częstym i swobodnym władaniu wszystkimi sprawnościami w języku ojczystym (wyjściowym) i innym (docelowym) w różnych okolicznościach i z różnymi uczestnikami aktu komunikacji. Wiąże się także z bliskim kontaktem z obydwiema kulturami i możliwością ich doświadczania/doznawania. Dwujęzyczność jest uwarunkowana nabywaniem/przyswajaniem języka jako drugiego, co odbywa się nieświadomie, w sposób pośredni, w zakresie komunikacji słuchowo-ustnej, bez planu, formalnych instrukcji, bez pomocy nauczyciela i kontroli, w naturalnym otoczeniu, wśród społeczności, dla której dany język jest językiem etnicznym (Krashen, Terrell 1983: 27).

Tove Skutnabb-Kangas (1981: 81) wyróżnia cztery kryteria warunkujące bilingwizm. Są nimi: pochodzenie, kompetencja, funkcja i nastawienie, a ich badaniem zajmują się różne dyscypliny naukowe ${ }^{9}$ (zob. tabela 1).

7 Jej użytkownicy zachowują taki język, który „wywieźli” lub który został im przekazany przez rodziców. Z powodu oddalenia od macierzy nie nadąża on za naturalnym rozwojem języka polskiego w Polsce, ulegając swego rodzaju zamrożeniu (Lipińska, Seretny, Turek, w druku).

$8 \mathrm{Na}$ możliwość wystąpienia rozdźwięku między kompetencją językową w języku rodzimym a odgrywaną rolą społeczną zwraca uwagę Miodunka (2014: 221), omawiając istotę lingwistyki humanistycznej.

9 Według W. Miodunki (1999: 312) dwujęzyczność jest zjawiskiem społecznym per se i wiąże się z różnymi aspektami: językowym, psychologicznym i społeczno-kulturowym. 
Tabela 1. Kryteria określania dwujęzyczności i ich konotacje z dyscyplinami naukowymi.

\begin{tabular}{ll}
\multicolumn{1}{c}{ Kryterium } & \multicolumn{1}{c|}{ Dyscyplina } \\
\hline pochodzenie (origin) & psychologia, psycholingwistyka \\
\hline kompetencja (proficiency) & lingwistyka \\
\hline funkcja/użycie & socjolingwistyka \\
\hline $\begin{array}{l}\text { nastawienie (attitude) - identyfikacja } \\
\text { wewnętrzna i zewnętrzna }\end{array}$ & socjolingwistyka, socjopsychologia \\
\hline
\end{tabular}

Źródło: Skutnabb-Kangas 1981: 18.

Kryteria te uważam za rudymentarne, mogące znacząco usprawnić klasyfikację pojęć dotyczących dwujęzyczności. Trzeba rozpatrywać je łącznie, odróżniając jednakże aspekty subiektywne (kryterium pochodzenia razem z nastawieniem) od obiektywnych (kryterium kompetencji oraz funkcji/użcia ${ }^{10}$ (zob. tabela 2).

Tabela 2. Czynniki warunkujące dwujęzyczność.

\begin{tabular}{ll}
\multicolumn{2}{c}{ Bilingwizm } \\
\hline czynniki subiektywne & czynniki obiektywne \\
\hline pochodzenie & kompetencja \\
\hline nastawienie & użycie/funkcja
\end{tabular}

(oprac. własne)

\subsubsection{Czynniki subiektywne}

Kryterium pochodzenia. Sytuacja, kiedy na obczyźnie obydwoje rodzice są tej samej narodowości (tu: polskiej) i mówią tym samym językiem, jest modelowa, stanowi punkt odniesienia dla innych, mniej lub bardziej skomplikowanych przypadków. Dzieci wychowane w takich rodzinach - bez względu na miejsce zamieszkania - z łatwością określają swój język ojczysty i rodzimą kulturę. Trzeba jednak mieć na uwadze fakt, że małżeństwom endogamicznym w transmisji polskości przychodzą z pomocą (często nieświadomie i niejawnie) zarówno rodzina żyjąca w pobliżu lub w Polsce, jak i środowisko polonijne (szkoły, instytucje kulturalno-oświatowe, kościoły) (więcej zob. Lipińska 2013). Natomiast w wyniku stale rosnącej liczby związków mieszanych powiększa się rzesza dzieci, którym jest o wiele trudniej

10 Taki podział w rzeczywistości może być nieostry. Tu dokonujemy go na potrzeby przejrzystości rozważań. 
zidentyfikować rdzenną kulturę i język ojczysty. Przykładem mogą być polsko-niemieckie małżeństwa mieszkające w Berlinie, które używając w domu dwu języków i pielęgnując dwie kultury, przekazują je dzieciom ${ }^{11}$. Matki Polki (o wiele częściej niż ojcowie Polacy) w parach egzogamicznych, żyjące poza krajem pochodzenia, są zdane tylko na siebie, osamotnione w swojej kulturze i językowości, których podtrzymywanie jest utrudnione i/lub ograniczone. Należy też pamiętać, że związki mieszane mają na ogół pomniejszoną rodzinę jednojęzyczną, tzn. jeśli nawet rodzice matki znają język jej kraju osiedlenia, to po pierwsze, nie jest wskazane, aby go używali w kontaktach z wnukami (Lipińska 2014), a po drugie, nie są wcale lub odpowiednio zanurzeni w danej kulturze i nie mogą przyczyniać się do jej rozwoju. Rodzime wartości zaś są przez nich przekazywane albo sporadycznie, albo nie w pełni.

Kryterium nastawienia. Stosunek do języka/języków i kultury/kultur może mieć kluczowe znaczenie dla ich akceptacji bądź odrzucenia. Najkorzystniejszą postawę przyjmują ludzie żywiący przekonanie, że obydwa języki są dla nich ojczyste (native-like languages), i mający poczucie przynależności do obydwu kultur i społeczności ${ }^{12}$. Mowa o wewnętrznej i zewnętrznej identyfikacji. O ile tę pierwszą da się stwierdzić samemu, odpowiadając na pytanie „Kim jesteś?/Za kogo się uważasz - za X czy za Polaka?", druga powinna być rozpoznana przez osoby z zewnątrz ${ }^{13}$. Jeśli uważają one daną jednostkę za swoją, można mówić o stanie równowagi identyfikacyjnej.

Powyższe kryteria warto rozpatrywać łącznie, gdyż warunkują się wzajemnie. Tak jest na przykład w wypadku dzieci z rodzin mieszanych - kryterium pochodzenia jest podwójne, a to może oznaczać, że wskazanie, który język jest uważany przez nie za ojczysty, nie jest oczywiste. Powoduje to wahania jednostek dotyczące identyfikacji wewnętrznej i nastawienia do obydwu kultur i języków.

Omówione czynniki mają silne uwarunkowanie socjalne. Nie mniej ważne jest podłoże psychologiczne ${ }^{14}$, wiążące się bezpośrednio z motywacją, stosunkiem do lokalnego języka i kultury, relacjami w rodzinie, emocjonalnym rozwojem jednostki; czynniki te wpływają również na określenie własnej tożsamości (zob. np. Lipińska 2013).

11 Zdaniem Josiane Boutet (1997: 26) jest to przykład bilingwizmu indywidualnego. Jest on postrzegany jako kazus pojedynczej osoby, umiejscowiony w specyficznych warunkach, takich jak: wyobcowanie w środowisku innojęzycznym i innokulturowym, brak wsparcia diaspory i/lub małżonka, niepełność rodziny (przez co rozumie się nie tylko samotne wychowywanie dziecka, ale i eurosieroctwo lub adopcje dzieci z zagranicy).

12 Przykładem jest sama Skutnabb-Kangas (1981: 18-19).

13 W badaniach przeprowadzonych wśród młodzieży polskiej w Chicago na pytanie: „Jak sądzisz za kogo uważają Cię rówieśnicy amerykańscy?” (Lipińska, Seretny 2012: 55-56) udzielone przez ankietowanych odpowiedzi są subiektywne, ponieważ wyrażają przypuszczenie, a nie stan faktyczny. Natomiast w badaniu polskiego chłopca stającego się jednostką dwujęzyczną w Australii (case study) pytanie o jego „australijskość” zadano nauczycielkom, które dziecko bardzo dobrze znały. Ich odpowiedzi uznać należy za obiektywne (Lipińska 2013: 160). 
Kryteria 'pochodzenia' i 'nastawienia' nie dają możliwości obiektywnego stwierdzenia, czy dana osoba jest dwujęzyczna, czy nie. Są one istotne w wymiarze indywidualnym, prywatnym, dlatego taki stan można nazwać bilingwizmem subiektywnym.

\subsubsection{Czynniki obiektywne}

Określenie funkcji/użycia pomaga stwierdzić, w jakim zakresie oraz natężeniu (jak często) używa się obydwu języków. Kryterium kompetencji zaś ułatwia ustalenie poziomu ich zaawansowania.

W klasycznej definicji Bloomfielda ${ }^{15}$ mowa jest o takim opanowaniu innego języka obcego przez daną jednostkę, że nie jest ona odróżniana od native speakera, przy czym nie występuje u niej utrata języka rodzimego. Włada więc obydwoma językami w „prawie naturalny” sposób. Uważam, że konstatacja ta jest bardzo trafna i może stanowić pewien wzorzec, wyznacznik w określaniu innych sytuacji - w tym znajomości (dwu) języków.

Definicja ta wywołuje jednak sporo kontrowersji, które w wielu wypadkach wynikają z błędnej interpretacji sformułowania biegłość, która nie odróżnia danej jednostki od rodowitego użytkownika języka, utożsamianego zazwyczaj z najwyższym, bezbłędnym i najlepszym z możliwych stopniem opanowania wszystkich aspektów obu kodów. Wszak gimnazjalista osiąga ,jedynie” poziom B2, a absolwent edukacji podstawowej - B1, ale to jest poziom rodzimego użytkownika języka ${ }^{16}$.

Rozważając problemy bilingwizmu, warto więc skoncentrować się na tym, czy dana jednostka w obydwu swoich środowiskach (nie) jest postrzegana jako obca językowo i/lub kulturowo, czyli określić jej kompetencje oraz odnieść się do kryterium użycia.

\section{Dwujęzyczność naturalna a inteligencka}

Sposób opanowania języka innego niż rodzimy, czyli nabywanie i/lub uczenie się, jest podstawą dychotomii: dwujęzyczność naturalna, nazywana również popularna lub ludowa (folk), oraz dwujęzyczność inteligencka, inaczej - elitarna (elite)

15 „In the extreme case of foreign language learning, the speaker becomes so proficient as to be indistinguishable from the native speakers round him [...]. In the cases where this perfect foreign-language learning is not accompanied by loss of the native language, it results in bilingualism, [the] native-like control of two languages" (za: Grosjean 1982: 231).

16 Jeśli język ojczysty nie jest przez daną jednostkę opanowany w pełni, tzn. nie jest uczony/nie został nauczony w szkole w zakresie wszystkich sprawności i podsystemów, jednostka ta jest uważana za analfabetę. Dlaczego inne zasady miałyby obowiązywać w języku obcym/drugim? 
(IEL 176, 183-184; Warchoł-Schlottmann 1994: 35; Skutnabb-Kangas 1981: 75-76; de Mejía 2002). Pierwsza kształtuje się w toku naturalnych interakcji i najczęściej występuje u imigrantów lub gastarbeiterów posługujących się językiem, który w danym państwie jest hegemoniczny. Jest to na przykład angielski nabywany przez Polaków w USA drogą nieformalną. Często także język rodzimy jest używany naturalnie, czyli w postaci słuchowo-ustnej w rodzinie, w kręgu przyjaciół i w środowisku polonijnym, słowem jego zasięg jest ograniczony do własnej diaspory. Istotą drugiej, wzmacnianej przyswajaniem lub powstałej na jego bazie, jest systematyczne uczenie się obcego kodu (to najczęściej jeden z międzynarodowych języków przydatnych w biznesie, nauce lub polityce). Dwujęzyczność taka powstaje zazwyczaj u wysoko wykształconych, społecznie mobilnych i dobrze sytuowanych jednostek, które pracują, odbywają staże bądź studiują za granicą. W szczególności zaś dotyczy dzieci z wyższych i średnich klas, które dużo podróżują, czasowo przebywają za granicą $\mathrm{z}$ rodzicami dyplomatami, biznesmenami, naukowcami itp. lub mieszkają tam na stałe. Bilingwizm elitarny jest więc nieprzypadkowy, wręcz odwrotnie - zainteresowani zdobywają go z rozmysłem, dobrowolnie, dlatego też bywa nazywany celowym (voluntary) (Skutnabb-Kangas 1981: 75). Oznacza to, że i dorośli, i dzieci chcą opanowywać nowy język, gdyż czują potrzebę porozumiewania się (nie tylko drogą ustno-słuchową) z tuziemcami. Starają się jednocześnie nie tracić języka ojczystego, gdyż tego typu pobyty są z reguły czasowe (za takie a priori uważane). Mając na względzie powrót do kraju, rodzice nie tylko naciskają na rozwój języka ojczystego, dbając o jego wysoki poziom, ale uczą go $\mathrm{w}$ domu lub posyłają swoje pociechy do polskich szkół ${ }^{17}$.

Ponieważ ludzie z wyższych sfer obracają się za granicą na ogół w podobnych kręgach jak w kraju, mieszkają w dobrych dzielnicach, rzadko wybierają zamknięte społeczności, gdzie mówi się językiem polonijnym (zob. p. 3.), mają szansę opanować nowy kod na podobnym (jak język rodzimy) poziomie. Dorośli uczą się go na kursach lub w szkołach językowych, ich dzieci zaś uczęszczają do miejscowych, zwykle renomowanych szkół. Uczestnicząc zaś w życiu społeczno-kulturalnym danego kraju, zyskuje się szansę swobodnego nabywania jego języka. Trzeba też pamiętać, że w rodzinie o wyższym statusie społeczno-ekonomicznym przeważnie więcej się czyta i korzysta z dóbr kultury, bardziej się dba o poprawność języka, o jego klasę, gdyż „przynależność do «lepszego» towarzystwa bezsprzecznie wymaga umiejętności posługiwania się «lepszym» językiem” (Hoffman 1995: 120). Nie świadczy to jednak o tym, że dzieci z rodzin uboższych nie mają szansy na osiągnięcie wysokiego poziomu biegłości w języku docelowym oraz ojczystym. Jest to jednak poważne utrudnienie, nieraz nie do pokonania (więcej zob. Lipińska 2013).

17 Zazwyczaj wybierają szkoły lokowane przy polskich placówkach dyplomatycznych (pozostające w ramach polskiego systemu edukacji) lub takie, w których miejscowe ministerstwa edukacji gwarantują naukę w języku polskim. W odróżnieniu od tzw. polonijnych sobotnich szkół obydwa typy placówek oświatowych zapewniają wysoki poziom nauczania (Lipińska, Seretny 2011). 
Jak wykazały badania Basila Bernsteina (1980), bardzo ważne są role społeczne pełnione przez poszczególnych członków rodziny. W tych nastawionych na osobę, typie częściej występującym w klasie średniej, stosunki są zwykle partnerskie. Determinuje to wielostronność komunikacji werbalnej - dzieci nie tylko odbierają, ale i nadają komunikaty, a więc mają bogatsze doświadczenie językowe od rówieśników z klas najniższych, w których dominują rodziny typu pozycjonalnego ${ }^{18}$.

Podsumowując powyższe refleksje, należy stwierdzić, że bilingwizm elitarny/inteligencki wynika z uczenia się zarówno innego (obcego lub drugiego), jak i rodzimego języka, wzmacniającego jego naturalne naby wa nie o podłożu intencjonalnym. Wiąże się to z zachowaniem własnej kultury i poznawaniem nowej przez jej doświadczanie, co wzmacnia $\operatorname{stan}^{19}$ dwujęzyczności i dwukulturowości.

\subsection{Bilingwizm kognitywny}

Określenie „inteligencki” odnosi się do wykształconej grupy ludzi, która niekoniecznie ma dobre warunki socjalne, zaś „elitarny” kojarzy się z kręgami uprzywilejowanymi, w tym ekonomicznie, choć nie zawsze należą do nich osoby wykształcone. Dlatego też uważam, że bardziej stosowną nazwą dla omawianego zjawiska jest $b i$ lingwizm kognitywny. Zakłada ona świadome i celowe uczenie się (języka i przez język) oraz zdobywanie wiedzy i umiejętności, a w konsekwencji umożliwia zbadanie stopnia opanowania obydwu języków w sposób obiektywny, czyli za pomocą testów/ egzaminów.

Bilingwizmu się nie mierzy, tylko zakłada, że istnieje. Podstawą są obserwacje uczestniczące (jawne lub ukryte) oraz fakty, które to potwierdzają. To na przykład bezproblemowe porozumiewanie się w sferach: prywatnej, publicznej, zawodowej, edukacyjnej $^{20}$, a więc zarówno nieformalne konwersacje, jak i komunikacja ustna oraz pisemna w pracy, w „dwujęzycznej” firmie.

Można ustalić stopień opanowania języka drugiego/obcego, przystępując do egzaminu certyfikatowego, ale poza systemem edukacji nie ma odpowiednich narzędzi sprawdzających poziom zaawansowania języka rodzimego. Określenie biegłości w obydwu językach i odniesienie jej do adekwatnych wiekowo i społecznie rodzimych użytkowników jest celowe szczególnie w okresie szkolnym, w wieku 8-9 do 13-14 lat. W tym czasie bowiem można skutecznie skorygować wszelkie braki czy niedoskonałości lingwistyczne. Testy takie nie istnieją, dlatego należy je stworzyć

18 Każdy członek rodziny ma w nich wyznaczoną pozycję i pełni tylko tę rolę, która została przez nią określona: ojca, matki, dziecka. Komunikacja jest zwykle jednostronna, tzn. albo jest się nadawcą, albo odbiorcą (Lipińska 2003).

19 Dwujęzyczność i dwukulturowość należy rozpatrywać w kategorii procesu, a nie właściwości posiadanej na zawsze.

2o W jednej z nich, dwu, trzech lub wszystkich (ESOKJ). 
dla konkretnej jednostki ${ }^{21}$. Powinny mieć postać testów osiągnięć, czyli takich, które są skorelowane z programem szkolnym i mierzą poziom opanowania przerobionego materiału.

Należy dobitnie podkreślić, że nie może być mowy o wystąpieniu bilingwizmu, jeśli język ojczysty nie zostanie opanowany/zachowany na zadowalającym poziomie, a zwłaszcza jeśli nie będzie adekwatny do pełnionej przez daną jednostkę roli społecznej i jej wieku. Ma to szczególnie głębokie konsekwencje w przypadku dzieci i młodzieży, dlatego rola, jaką w przekazywaniu polskości odgrywają rodzice, jest nie do przecenienia (Lipińska 2003, 2013, 2014). Największym błędem jest rezygnacja $\mathrm{z}$ porozumiewania się z potomstwem po polsku i usiłowanie przejścia na język kraju osiedlenia. Zdarza się to częściej - zdaniem Laskowskiego (2009) - u gorzej wykształconych osób, z kompleksem niższości kulturowej, które władają nim w stopniu ograniczonym, używając „sprymityzowanej, ubogiej leksykalnie, kalekiej gramatycznie, niezniuansowanej stylistycznie jego formy" (Laskowski 2009: 11). Ponieważ ani jeden, ani drugi język nie jest dobrze opanowany, nie tylko zostaje zakłócona komunikacja w rodzinie, ale także w kręgu rówieśników dziecko pozostaje językowo niepełnosprawne, a to prowadzi do zahamowań jego kognitywnego i emocjonalnego rozwoju (ibid.). Niezapoznawanie własnych dzieci z językiem i kulturą matki lub ojca występuje także wtedy, gdy napływowy rodzic doskonale włada językiem kraju osiedlenia i bez problemów porozumiewa się w nim z partnerem, odkładając polskość syna/córki na później. To prawie zawsze jest polskość stracona.

Znaczenie dbałości o język ojczysty na obczyźnie rośnie, jeśli uzmysłowimy sobie, że dla większości (e/i)migrantów (zarówno z pokolenia polonijnego, jak i zerowego, zob. Lipińska, Seretny 2013) stanowi on język wyjściowy w przyswajaniu i nauce języka docelowego.

\section{Język wyjściowy}

W znacznym uproszczeniu można powiedzieć, że w odmianie zagranicznej polszczyzny $^{22}$ mamy do czynienia z językiem standardowym/literackim, polonijnym i odziedziczonym (heritage language ${ }^{23}$.

Języka standardowego używa warstwa inteligencji, a więc osoby wykształcone, które mają wyższy stopień świadomości językowej i dbają o poprawność polszczyzny. Jest ona bardzo zbliżona do języka narodowego używanego w Polsce, obejmuje

21 Testy takie opracowałam na potrzeby zbadania kompetencji polskiego dziecka przebywającego w Australii (Lipińska 2009, 2013).

22 O odmianach języka (i ich zróżnicowanym nazewnictwie) zbiorowości polonocentrycznych więcej (Miodunka 1990; Dubisz 1997).

23 Bardziej szczegółowo (Lipińska, Seretny 2009, 2012). Ten nieco przejaskrawiony podział jest pomocny w przedstawieniu złożoności pojęcia język polski na obczyźnie. 
więc dobrą znajomość wszystkich podsystemów i sprawne posługiwanie się językiem. Zdaniem W. Miodunki:

[...] byłoby bardzo pożądane, gdyby wszyscy mówiący po polsku poza Polską znali polszczyznę literacką, bo to w niej wyraża się tożsamość polską, wyraża się solidarność ze wszystkimi, którzy gdziekolwiek na świecie mówią po polsku (Miodunka 1999: 316).

Językiem polonijnym nazywa się polszczyznę używaną na co dzień. Są to ustne odmiany mieszane (regionalno-gwarowe), pozostające pod wyraźnym wpływem języka kraju osiedlenia, występujące w enklawach terytorialnych i socjalnych. Zazwyczaj posługują się nimi ludzie o niższym wykształceniu i statusie społecznym, mniej wrażliwi na poprawność wypowiedzi. Z odmianami mieszanymi kojarzy się pojęcie interjęzyka (interlanguage), który stanowi sumę kompetencji w języku wyjściowym i docelowym oraz reguł przynależnych wyłącznie danej osobie ${ }^{24}$.

Język odziedziczony jako określenie nadrzędne w stosunku do wcześniej wspomnianych (zob. tabela 3) to polszczyzna w postaci mówionej, używana głównie w środowisku rodzinnym. Ma większość cech języka polonijnego, ale na ogół bez domieszki lokalnego kodu. Język odziedziczony może być tożsamy z językiem domowym zawężonym do tematów związanych ze sprawami życia codziennego. Jego użytkowników można określić mianem mówiący językiem odziedziczonym (MJOD) (heritage language speakers, HLS), (zob. też Lipińska, Seretny 2013). Jeśli jednak staje się on przedmiotem i środkiem nauczania w polskich szkołach, przybiera inną postać. Stapia się wówczas z językiem literackim, wyrażając i odzwierciedlając w pełniejszym zakresie historyczno-kulturowo-emocjonalną głębię polskości oraz mocniej podkreślając przynależność uczących się do kultury przodków. Użytkownicy kodu w takiej postaci to uczacy się języka odziedziczonego (UJOD) (heritage language learners - not speakers, HLL) ${ }^{25}$.

Rozgraniczenie języka odziedziczonego w wersji mówionej (domowego) od jego wariantu edukacyjnego, w wersji mówionej i pisanej, ma silne powiązania z podziałem na dwujęzyczność naturalną i kognitywna, o których była wcześniej mowa.

$24 \mathrm{Z}$ tego powodu kod ten jest także nazywany dialektem idiosynkratycznym.

25 Spotyka się jednostki używające polszczyzny literackiej w zakresie słuchowo-ustnym. Zazwyczaj są to dzieci w rodzinach inteligenckich, które jednak wcześniej czy później muszą dołączyć do grona uczących się języka odziedziczonego. Mogą nimi być dorośli, ale ci mają już jakieś wykształcenie, więc nie muszą się języka uczyć, ale jedynie pielęgnować go i rozwijać (Lipińska, Seretny, Turek, w druku). 
Schemat 1. Język odziedziczony a dwujęzyczność.

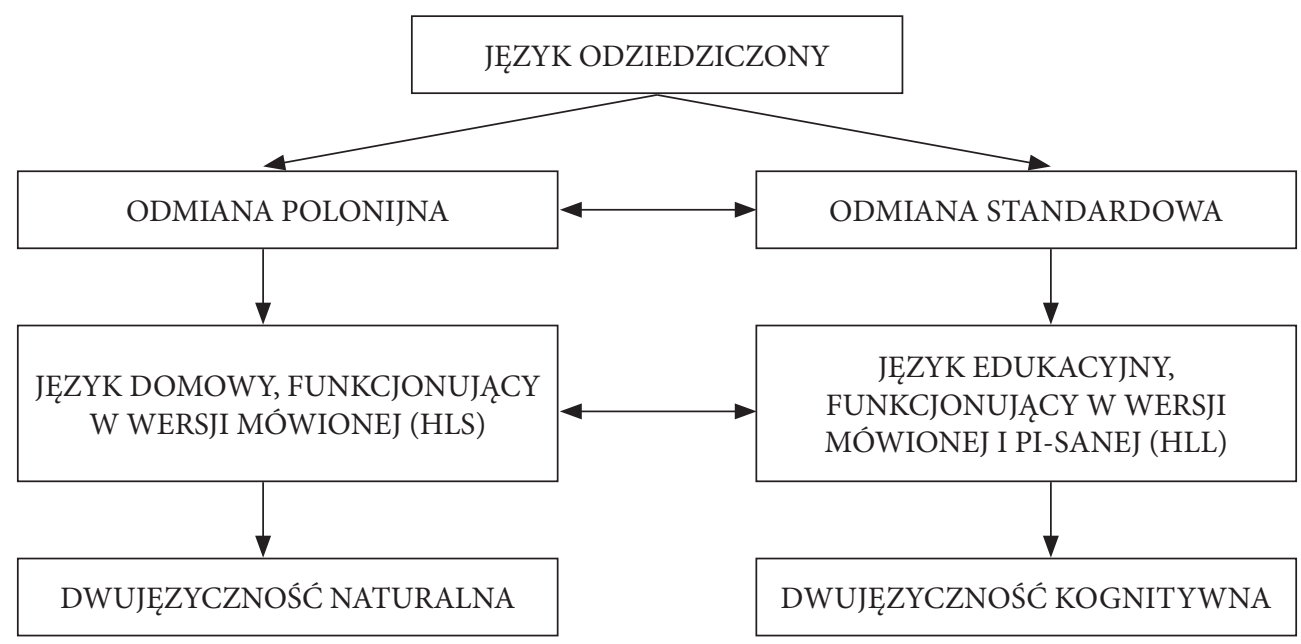

(oprac. własne)

Warto nadmienić, że Miodunka (2003: 256-257) proponuje odgraniczenie ${ }^{26}$ odmiany języka używanego przez Polaków zamieszkałych za granicą w dzieciństwie, nazywając ją macierzystą ${ }^{27}$, od poznanej/wyuczonej w późniejszym wieku odmiany literackiej, ogólnej. O ile posługiwanie się polszczyzną w dzieciństwie było spontaniczne, o tyle późniejsza jej wersja jest ciągle kontrolowana, przepuszczana przez filtr reguł gramatycznych. Są to „dwa różne języki i dwa różne światy, obce sobie”, a nie dwie odmiany tego samego języka (ibid.: 256) ${ }^{28}$.

Należy podkreślić zawiłość pojęcia język wyjściowy (zob. tabela 4), który często jest trudny do określenia (w rodzinach mieszanych) i daleki od jednolitości. Ma on w dodatku cechy dyglosji polonijno-polskiejej

26 Podział ten odnosi się do Polonii brazylijskiej. Autor zalicza do odmiany 'macierzystej’ język potoczny z elementami gwarowymi, gwarę, interdialekt. Uważa, że odmiana ta niesie ze sobą większy ładunek uczuciowy, skojarzenie związanie z matką i nie oznacza to bynajmniej, że jest to kod ograniczony (nazywany „polszczyzną kuchenną”).

27 Termin język macierzysty jest zbliżony do nazewnictwa światowego: mother tongue, langue maternelle, Muttersprache. Podobnie widzi to Lipińska (2012: 22), traktując go jednak jako nadrzędny w stosunku do określeń: język ojczysty, pierwszy, rodzimy, prymarny, etniczny, odziedziczony, wyjściowy.

28 Zdarza się, że poznawszy literacką wersję polszczyzny, jej użytkownicy mają poważny dylemat, jak zwracać się do swoich bliskich, którzy operują tylko jego 'domową formą. Często „wolą używać języka obcego (angielskiego, portugalskiego, francuskiego itd.), bo czują, że język literacki, którego się nauczyli, to inny język, to nie jest autentyczny język rodziców i dziadków" (Miodunka 2003: $256-257)$.

29 Język domowy vs edukacyjny (Lipińska 2003, 2012). 
Tabela 3. Język wyjściowy i język docelowy.

\begin{tabular}{|l|l|l|l|l|}
\hline \multirow{2}{*}{ Język wyjściowy } & $\begin{array}{l}\text { odmiana } \\
\text { macierzysta }\end{array}$ & domowy & polonijny & $\begin{array}{l}\text { polszczyzna } \\
\text { standardowa }\end{array}$ \\
\hline \multirow{2}{*}{ Język docelowy } & \multirow{2}{*}{ odmiana ogólna } & \multicolumn{2}{|c|}{ polszczyzna standardowa } & \multirow{2}{*}{ obcy/drugi } \\
\cline { 2 - 4 } & \multicolumn{2}{|r|}{ obcy/drugi } & \\
\hline
\end{tabular}

(oprac. własne)

\section{Podsumowanie}

Osadzenie dwujęzyczności w kontekście glottodydaktycznym pozwala na wyraźne wyodrębnienie bilingwizmu kognitywnego, którego istnienie można nie tylko obiektywnie stwierdzić, poddając pomiarowi różne aspekty biegłości językowej danej jednostki, ale i obserwować dynamikę jego rozwoju. Dzięki temu da się też przeciwdziałać jego zanikowi, co w przypadku młodego pokolenia (e/i)imigranckiego zazwyczaj oznacza zamrożenie kompetencji lub regres w języku ojczystym. Nie jest to zjawisko częste ani trwałe. Znacznie szerszy zasięg ma znajomość dwu języków osiągana w drodze naturalnego nabywania nowego języka lub uczenia się go w sztucznych warunkach. Jego stopień zaawansowania przewyższa poziom znajomości języka ojczystego lub jest od niego znacznie niższy. Zaburzony jest również stosunek do kultury rodzimej i nowej. Obydwa sposoby opanowywania języka obcego/drugiego nie mają punktów stycznych lub mają ich niewiele.

Zarówno w przypadku bilingwizmu, jak i znajomości (dwu) języków zasadniczą rolę odgrywa język odziedziczony, który jako wyjściowy w opanowywaniu języka drugiego/obcego oraz przyswajaniu i uczeniu się polszczyzny standardowej/literackiej (edukacyjnego języka odziedziczonego) jest dość zróżnicowany. Taką świadomość powinni posiadać uczący, uczący się i ich rodzice, a także badacze i autorzy prac poświęconych bilingwizmowi.

\section{Literatura}

Bernstein B., 1980, Socjolingwistyczne ujęcie procesu socjalizacji. Uwagi dotyczace podatności na oddziaływania szkoły, [w:] G.W. Shugar, M. Smoczyńska (red.), Badania nad rozwojem jezzyka dziecka, Warszawa.

Boutet J., 1997, Langage et societé, Paris.

DuBIsz S., 1997, Język polski poza granicami kraju - wstępne informacje i definicje, [w:] idem (red.), Język polski poza granicami kraju, Opole, s. 13-46.

ESOKJ: Europejski system opisu kształcenia językowego: uczenie się, nauczanie, ocenianie, Warszawa 2003. 
Grosjean F., 1982, Life with Two Languages. An Introduction to Bilingualism, Cambridge.

Hoffman E., 1995, Zagubione w przekładzie, Londyn.

IEL: International Encyclopedia of Linguistics, red. W. Bright, New York 1992.

Krashen S., Terrell T., 1983, The Natural Approach. Language Acquisition in the Classroom, Oxford.

LASKowski R., 2009, Język w zagrożeniu. Przyswajanie języka polskiego w warunkach polsko-szwedzkiego bilingwizmu, Kraków.

LipińsKa E., 2003, Język ojczysty, język obcy, język drugi. Wstęp do badań dwujęzyczności, Kraków.

LipıŃsKa E., 2006, Przyswajanie języka pierwszego a uczenie się języka obcego/drugiego, [w:] E. Lipińska, A. Seretny (red.), Z zagadnień dydaktyki języka polskiego jako obcego, Kraków, s. 19-28.

LipińsKa E., 2009, Sprawdzian stopnia opanowania języka drugiego i poziomu znajomości języka ojczystego u dzieci na emigracji, „Języki Obce w Szkole” nr 5, s. 74-86.

LIPIŃSKA E., 2012, "Język polski” - przegląd terminologii stosowanej w glottodydaktyce polonistycznej, [w:] E. Lipińska, A. Seretny, Między językiem ojczystym a obcym. Nauczanie i uczenie się języka odziedziczonego w chicagowskiej diasporze polonijnej, Kraków, s. $19-31$.

Lipińska E., 2013, Polskość w Australii - o dwujęzyczności, edukacji i problemach adaptacyjnych Polonii na antypodach, Kraków.

LiPIŃsKa E., 2014, Dwujęzyczność pokolenia polonijnego - jak ją zdobyć i zachować, „Polski w Niemczech. Pismo Federalnego Związku Nauczycieli Języka Polskiego" nr 2, s. 5-18.

Lipińska E., Seretny A., 2009, O polszczyźnie literackiej na obczyźnie, „Postscriptum Polonistyczne" nr 2(4), s. 145- 65.

Lipińska E., Seretny A., 2011, Doświadczenia nauczania w skupiskach polonijnych. Raport przygotowany na III Kongres Polskich Towarzystw Naukowych na Obczyźnie, on-line: www.swp.krakow.pl/panel/spaw2/uploads/files/seretny.pdf (dostęp: II 2015).

LipińsKa E., SERETny A., 2012, Między językiem ojczystym a obcym. Nauczanie i uczenie się języka odziedziczonego w chicagowskiej diasporze polonijnej, Kraków.

Lipińska E., Seretny A., 2013, Nie swój, lecz i nie obcy. Język odziedziczony w perspektywie glottodydaktycznej, [w:] Materiały $z$ konferencji „Młoda polska emigracja $w$ UE jako przedmiot badań psychologicznych, socjologicznych i kulturowych EuroEmigranci.PL", Kraków 23-24 IX 2013 r., on-line: www.euroemigranci.pl/dokumenty/pokonferencyjna/ Seretny_Lipinska.pdf (dostęp: II 2015).

Lipińska E., Seretny A., Turek P., w druku, Ta sama, lecz nie taka sama polszczyzna Polaków zza granicy, cudzoziemców i rodzimych użytkowników języka.

MejíA A.-M.DE, 2002, Power, Prestige, and Bilingualism: International Perspectives on Elite BilingualEducation, on-line: www.searchworks.stanford.edu/view/4780297 (dostęp: II 2015).

Miodunka W., 1990, Wstęp, [w:] idem (red.), Język polski w świecie. Zbiór studiów, Warszawa, s. 9-20.

Miodunka W., 1999, Język polski poza Polska, [w:] W. Pisarek (red.), Polszczyzna 20oo. Orędzie o stanie języka na przełomie tysiącleci, Kraków, s. 306-323.

Miodunka W.T., 2003, Bilingwizm polsko-portugalski w Brazylii. W stronę lingwistyki humanistycznej, Kraków.

Miodunka W.T., 2014, Dwujęzyczność polsko-obca w Polsce i poza jej granicami. Rozwój i perspektywy badań, „LingVaria” IX, nr 1, s. 199-226. 
Peal E., Lambert W.E., 2007, Związek dwujęzyczności z inteligencją, [w:] I. Kurcz (red.), Psychologiczne aspekty dwujęzyczności, Gdańsk, s. 229-268.

Skutnabb-Kangas T., 1981, Bilingualism or not: The Education of Minorities, Multilingual Matters, London.

Warcho£-Schlottmann M., 1994, Próba opisu kompetencji językowej w niemieckim i polskim u Polaków w Niemczech - studium socjolingwistyczne, Kraków, rozprawa doktorska, mps.

\section{Cognitive bilingualism \\ Summary}

The paper makes a clear distinction between cognitive bilingualism and knowledge of two languages. The first term is embedded in the context of education, it can be measured and its development can be followed; the second is understood as mastering, but only partially, of one or both languages. Moreover, the article identifies subjective and objective factors that influence the perception of bilingualism and biculturalism, and emphasizes the ambiguity of the term first language, together with the essence of heritage language.

My considerations refer to Polish diaspora, and to situations where one of the languages is Polish and the other (the second/foreign one) is another European language. 